\title{
Quantitative Determination of HIV-Antiviral Agent using Complexing Reagent in Bulk Material and Formulations
}

\section{THUTTAGUNTA MANIKYA SASTRY ${ }^{1 *}$, KARIPEDDI RAMAKRISHNA ${ }^{2}$ KOTTURU VENKATA LAVANYA ${ }^{3}$ and KALLEMPUDI SIVA PRASAD ${ }^{4}$}

\author{
'Department of Chemistry, G V P College of Engineering (Autonomous), \\ Madhurwada, Visakhapatnam - 530 048, India. \\ ${ }^{2}$ Department of Chemistry, GITAM University, Rushikonda, Visakhapatnam - 530 045, India. \\ ${ }^{3}$ Department of Humanities and Basic Sciences, Chaitanya Engineering College, \\ Kommadi Junction, Visakhapatnam - 530 048, India. \\ ${ }^{4}$ Department of Basic Sciences and Humanities, Vignan's Institute of Information Technology, \\ Duvvada, Visakhapatnam - 530 049, India. \\ ${ }^{*}$ Corresponding author E-mail: tmsastry@yahoo.com
}

http://dx.doi.org/10.13005/ojc/300144

(Received: December 15, 2013; Accepted: January 17, 2014)

\begin{abstract}
A sensitive visible spectrophotometric method was developed for quantitative determination of Antiviral [Abacavir sulphate (AVS)] agent against HIV in bulk material and dosage forms. An extraction spectrophotometric method for the assay of abacavir sulphate is based on the formation of colored co-ordination complex with cobalt thiocyanate (CTC) which can be extractable in nitrobenzene $\left(\lambda_{\max }=620 \mathrm{~nm}\right)$ is described. Beer's law limits and molar absorptivity values were found to be $10-$ $50 \mu \mathrm{g} \mathrm{mL}^{-1}$ and $9.58 \times 10^{3} \mathrm{~L} \mathrm{~mol}^{-1} \mathrm{~cm}^{-1}$ respectively. The limit of detection and limit of quantification values are found to be $3.07 \times 10^{-1} \mathrm{\mu g} \mathrm{mL}^{-1}$ and $9.3 \times 10^{-1} \mathrm{Mg} \mathrm{mL}^{-1}$ respectively. Precision and accuracy of the developed method was evaluated. The results are validated statistically and compared with reported methods.
\end{abstract}

Key words: Spectrophotometry, Abacavir sulphate, Ziagen Nitrobenzene, Cobalt thiocyanate (CTC) and dosage forms.

\section{INTRODUCTION}

Abacavir is an antiviral agent which is carbocyclic synthetic nucleoside analogue with inhibitory activity against HIV. The chemical name of Abacavir sulphate is: [(1S, 4R) - 4 - [2 - Amino - 6 - (cyclopropylamino) - 9H - purin - 9 - yl] -2 -cyclopentene-1-methanol sulphate (salt) $(2: 1)]$ (Fig. 1). In literature, a number of analytical methods have been described for estimation of AVS including electrochemical determination ${ }^{1}$, HPLC ${ }^{2,3}$, LC $^{4,5}$ and LC-MS ${ }^{6,7}$, and UV8-10 methods. But, relatively little attention has been paid in developing visible spectrophotometric methods ${ }^{11-15}$. The analytically 
important functional groups in AVS have not been exploited properly so far and hence there is a need to develop sensitive and flexible visible spectrophotometric methods. So authors have made some attempts in this direction and succeeded in developing more accurate, reliable and economical analytical method using cobalt thocyanate (CTC) for quantitative determination of AVS in bulk material and formulations.

\section{EXPERIMENTAL}

\section{Instrumentation}

The measurements were made on a SL177 model (Elico, India) visible spectrophotometer with $1 \mathrm{~cm}$ glass cells and on a UNICAM UV 500 spectrophotometer (Thermo Electron Corporation, UK). All pH measurements were made using a $\mathrm{LI}$ 120 digital pH meter (Elico, India).

\section{Reagents and materials}

All the reagents were of analytical grade and all solutions were prepared in double distilled water. Aqueous solutions of CTC (BDH; $\left.2.5 \times 10^{-1} \mathrm{M}\right)$, buffer solution $\left(p^{H}=2.0\right)$. and Nitrobenzene (Qualigens) solvent are used. The bulk drug Abacavir sulphate (Ranbaxy laboratories Ltd., India) was selected for the study. Formulation, Ziagen (Glaxo- welcome Inc., India) containing Abacavir sulphate was purchased from local commercial sources. Tablets equivalent to $300 \mathrm{mg}$ of different batches were selected for this study.

\section{Standard drug solution}

The free base solution ( $\left.\mathrm{mg} \mathrm{mL}^{-1}\right)$ was prepared by mixing $100 \mathrm{mg}$ of bulk drug with $10.0 \mathrm{ml}$ of $10 \% \mathrm{Na}_{2} \mathrm{CO}_{3}$ solution. The resulting solution was taken into a $150 \mathrm{ml}$ separating funnel and extracted with $3 \times 25 \mathrm{~mL}$ portions of chloroform and combined chloroform layer was brought up to $100 \mathrm{~mL}$ with the same solvent. A portion of the above free base stock ( $\mathrm{mg} \mathrm{mL}^{-1}$ ) solution was further diluted stepwise with the same solvent to obtain working standard solution of $100 \mu \mathrm{g} \mathrm{mL}^{-1}$

\section{Analytical procedure}

Aliquots of standard drug (free base form) solution $\left(1.0-5.0 \mathrm{~mL} ; 100 \mu \mathrm{gL}^{-1}\right)$, were delivered into series of calibrated tubes and solvent was completely removed by gentle heating on a boiling water bath. To the residue in each tube, $2.0 \mathrm{ml}$ of buffer ( $\mathrm{pH} 2.0$ ) and $5.0 \mathrm{~mL}$ of $2.5 \times 10^{-1} \mathrm{M} \mathrm{CTC}$ solutions were added. The total volume of aqueous phase in each separating funnel was adjusted to 15.0 $\mathrm{mL}$ with distilled water. These solutions in the test tubes were transferred to $125 \mathrm{~mL}$ separating funnels. To each separating funnel $10.0 \mathrm{~mL}$ of nitrobenzene was added and the contents were shaken for $2 \mathrm{~min}$. The two phases were allowed to separate and the absorbances of the separated nitrobenzene layer were measured at $620 \mathrm{~nm}$ against a similar reagent blank after $10 \mathrm{~min}$. The amount of drug (AVS) was deduced from its calibration curve. (Figure 3 )

\section{Pharmaceutical formulations}

Since only one formulation is available (Tablets), four different batches of this formulation were collected and analyzed as 4 sets to verify the validity of proposed methods. Accurately weighed quantity of tablet powder equivalent to $100 \mathrm{mg}$ of AVS was extracted with methanol ( $3 \times 25.0 \mathrm{~mL}$ portions) and filtered. The volume of combined extract was evaporated to dryness. The residue was used to prepare free base stock solution $\left(\mathrm{mg} \mathrm{mL}^{-1}\right)$ and working standard solution of concentration $100 \mu \mathrm{g}$ $\mathrm{mL}^{-1}$ as described in the standard drug solution. UV spectrophotometric method which was suggested for the identification of drug has been moulded for its assay and chosen as the reference method for ascertaining the accuracy of the proposed method.

\section{RESULTS AND DISCUSSION}

\section{Optimization of reaction conditions}

Optimum conditions for the proposed method were established by varying one parameter at a time and keeping the others fixed and observing the effect produced on the absorbance of the colored species. The effects of various parameters such as buffer solution, concentration of the CTC, organic solvent used for extraction, ratio of organic phase to aqueous phase during extraction, stability period and intensity of colored species were studied. The optimum conditions were as follows: $4.5-6.5 \mathrm{~mL}$ $\left(1.1-1.6 \times 10^{-1} \mathrm{~mol} \mathrm{~L}^{-1}\right)$ of CTC solution, $1.5-2.5 \mathrm{~mL}$ $\left(1.5-2.5 \times 10^{-2} \mathrm{~mol} \mathrm{~L}^{-1}\right)$ of buffer solution ( $\left.\mathrm{P}^{\mathrm{H}} 2.0\right), 1-4$ min. of shaking time ,the ratio of aqueous to organic phase on extraction is $3: 2$. In this procedure, $5.0 \mathrm{~mL}$ of $\left(1.3 \times 10^{-3} \mathrm{~mol} \mathrm{~L}^{-1}\right) \mathrm{CTC}, 2.0 \mathrm{~mL}\left(2.0 \times 10^{-2} \mathrm{~mol} \mathrm{~L}^{-1}\right)$ buffer solution and $2 \mathrm{~min}$. shaking period required for 
maximum color. Nitrobenzene was preferred for its selective extraction of the complex from the aqueous phase. The ratio of aqueous to organic phase on extraction was taken as 3:2. The colored species were stable for $40 \mathrm{~min}$. The $\lambda_{\max }(\mathrm{nm})$ and $\mu_{\max }\left(\mathrm{Lmol}^{-}\right.$ $\left.{ }^{1} \mathrm{~cm}^{-1}\right)$ values were found to be 620 and $9.589 \times 10^{3}$ respectively.

\section{Absorption spectrum}

For the selection of analytical wavelength, $100 \mathrm{mg} \cdot \mathrm{ml}^{-1}$ solution of abacavir sulphate was prepared by appropriate dilution of standard stock solution and scanned in the spectrum mode from $800 \mathrm{~nm}-400 \mathrm{~nm}$. The spectrum of the colored species produced by the suggested procedure is shown to possess maximum absorbance at $620 \mathrm{~nm}$

Table 1: Optical characteristics of the proposed method

\begin{tabular}{ll}
\hline Name of the parameter & CTC Method \\
\hline$\lambda_{\max }(\mathrm{nm})$ & 620 \\
Beer's Law limits) $(\mu \mathrm{g} / \mathrm{ml})$ & $10-50$ \\
Molar absorptivity $\left(\mathrm{L} \mathrm{mol}{ }^{-1} \mathrm{~cm}^{-1}\right)$ & $9.58 \times 10^{3}$ \\
Sandell's sensitivity $\left(\mathrm{mg} / \mathrm{cm}^{2} / 0.001\right.$ Absorbance unit $)$ & $6.99 \times 10^{2}$ \\
Limit of detection $(\mu \mathrm{g} / \mathrm{ml})$ & $3.07 \times 10^{-1}$ \\
Limit of quantification $(\mu \mathrm{g} / \mathrm{ml})$ & $9.3 \times 10^{-1}$ \\
\hline
\end{tabular}

Table 2: Regression parameters of proposed method

\begin{tabular}{ll}
\hline Regression parameter & CTC Method \\
\hline Regression equation $(\mathrm{Y}=\mathrm{a}+\mathrm{bC})^{*}$ & $\mathrm{Y}=0.00143 \mathrm{C}+0.0012$ \\
Slope $(\mathrm{b})$ & $1.43 \times 10^{2}$ \\
Standard Deviation on slope $\left(\mathrm{S}_{\mathrm{b}}\right)$ & $4.0 \times 10^{5}$ \\
Intercept $(\mathrm{a})$ & $-1.2 \times 10^{-3}$ \\
Standard Deviation on intercept $\left(\mathrm{S}_{\mathrm{a}}\right)$ & $1.33 \times 10^{3}$ \\
Correlation coefficient $(\mathrm{r})$ & 0.9999 \\
\end{tabular}

$\mathrm{Y}=\mathrm{a}+\mathrm{bC}$ where $\mathrm{C}$ is the concentration of analyte in $\mathrm{mg} / \mathrm{ml}$ and $\mathrm{Y}$ is the absorbance unit.

Table 3: Evaluation of precision and accuracy of proposed method

\begin{tabular}{|c|c|}
\hline Precession and accuracy parameter & CTC Method \\
\hline \multicolumn{2}{|l|}{ Precision (RSD) ${ }^{a}$} \\
\hline Intra-day reproducibility (RSD, \%) & 0.55 \\
\hline Inter-day reproducibility (RSD, \%) & 0.44 \\
\hline \multicolumn{2}{|l|}{$\%$ range of error ${ }^{b}$} \\
\hline Confidence limit at 0.05 level (95 \%) & \pm 0.58 \\
\hline Confidence limit at 0.01 level (99 \%) & \pm 0.91 \\
\hline a: Average of six determinations $(n=6)$ & concentration: \\
\hline $100 \mu \mathrm{g} \mathrm{mL}^{-1}$ & \\
\hline
\end{tabular}


which was selected for the analysis (Fig. 2). The calibration curve was prepared in the concentration range of $10-50 \mathrm{mg} \mathrm{mL}^{-1}$ at $620 \mathrm{~nm}$. By using the calibration curve (Fig.3), the concentration of the sample solution can be determined. The linearity was found in the concentration range of $10-50 \mathrm{mg}$ $\mathrm{mL}^{-1}$ as shown in the Figure 2.

\section{Mechanism of Reaction}

The coloured species formed can be regarded as a co-ordinate complex of the drug (electron donor) and the central metal atom of cobalt thiocyanate (electron acceptor) which is extractable into nitrobenzene from aqueous solution Formation of the blue coloured complex when AVS is treated with CTC due to the presence of aliphatic secondary group is the basis in the present investigation. It was observed that the drug (AVS), Cobalt and thiocyanate were in the ratio of 2:1:4 in the complex. The probable sequence of reactions based on analogy in previous work $^{16-17}$ is presented in Scheme.

\section{Method of validation}

The developed method was validated as

Table 4: Rrecovery studies by standard addition method

\begin{tabular}{|c|c|c|c|c|}
\hline $\begin{array}{l}\text { Proposed } \\
\text { method }\end{array}$ & $\begin{array}{c}\text { Formulation } \\
\text { Taken (A) } \\
\left(\left(\mu \mathrm{g} \mathrm{ml}^{-1}\right)\right.\end{array}$ & $\begin{array}{c}\text { Pure drug } \\
\text { added (B) } \\
\left(\mu \mathrm{g} \mathrm{ml}^{-1}\right)\end{array}$ & $\begin{array}{c}\text { Total drug con. } \\
(A+B) \\
\left(\left(\mu \mathrm{g} \mathrm{ml}^{-1}\right)\right.\end{array}$ & $\begin{array}{c}\% \text { Recovery }^{\mathrm{a}} \\
\pm \mathrm{SD} \\
\text { Ziagen }\end{array}$ \\
\hline СТС & 10 & 8 & 18 & $100.2 \pm 1.2$ \\
\hline СТС & 10 & 10 & 20 & $99.9 \pm 0.7$ \\
\hline CTC & 10 & 12 & 22 & $100.1 \pm 1.5$ \\
\hline
\end{tabular}

a: Average value of 3 determinations

Table 5: Assay of AVS in the presence of excipients ${ }^{\text {a }}$

\begin{tabular}{lcc}
\hline Excipient & Concentration $\left(\mathrm{mg} \mathrm{mL}^{-1}\right)$ & Recovery (\%)a,b \\
\hline Colloidal silicon dioxide & 3.0 & $99.9 \pm 0.6$ \\
Magnesium sterate & 4.0 & $99.8 \pm 0.5$ \\
Microcrystalline cellulose & 3.0 & $99.8 \pm 0.2$ \\
Sodium starch glycolate & 5.0 & $100.3 \pm 0.4$ \\
\hline
\end{tabular}

a: Concentration of drug $100 \mathrm{mg} \mathrm{ml}^{-1}, \mathrm{~b}$ : Mean $\pm \mathrm{SD}, n=5$.

Table 6: Assay of AVS in pharmaceutical formulations

\begin{tabular}{|c|c|c|c|c|c|c|}
\hline $\begin{array}{l}\text { Formu- } \\
\text { Lations } \\
\text { Tablet }\end{array}$ & $\begin{array}{c}\text { Labelled } \\
\text { Amount } \\
\text { (mg) }\end{array}$ & $\begin{array}{l}\text { Amount found } \\
\text { by proposed } \\
\text { methods } \\
(\mathrm{mg})^{\mathrm{a}, \mathrm{b}} \\
\text { CTCMethod }\end{array}$ & $\begin{array}{l}\text { F-test } \\
\text { value }\end{array}$ & $\begin{array}{l}\text { t-test } \\
\text { value }\end{array}$ & $\begin{array}{l}\text { Reference } \\
\text { Method }^{c}\end{array}$ & $\begin{array}{c}\text { \% Recovery } \\
\text { by proposed } \\
\text { methods }^{d} \\
\text { CTC Method }\end{array}$ \\
\hline Ziagen(Batch-I) & 300 & $301.5 \pm 2.8$ & 1.02 & 0.88 & $298.9 \pm 2.8$ & $100.5 \pm 0.9$ \\
\hline Ziagen(Batch-II) & 300 & $299.2 \pm 2.9$ & 2.73 & 2.12 & $300.6 \pm 1.8$ & $99.7 \pm 0.96$ \\
\hline Ziagen(Batch-III) & 300 & $298.8 \pm 2.8$ & 3.58 & 0.47 & $299.4 \pm 1.5$ & $99.66 \pm 0.92$ \\
\hline Ziagen(Batch-IV) & 300 & $300.7 \pm 4.9$ & 4.71 & 0.25 & $299.7 \pm 2.2$ & $100.2 \pm 1.6$ \\
\hline
\end{tabular}

a : Mean $\pm \operatorname{SD}(n=6)$

$c:$ Mean \pm SD $(n=3) 272$ $\mathrm{b}:$ Theoretical values of $95 \%$ confidence limit, $F=5.05, t=2.57$

$d$ : Average of three determinations $(n=3)$ 
Table 7: Comparison of proposed method with reported methods for Abacavir sulphate

\begin{tabular}{|c|c|c|c|c|c|c|c|}
\hline $\begin{array}{l}\text { Reagents } \\
\text { used }\end{array}$ & $\begin{array}{c}\lambda_{\max } \\
(\mathrm{nm})\end{array}$ & $\begin{array}{c}\text { Beer's } \\
\text { Law } \\
\text { Limits } \\
\left(\mu \mathrm{g} \mathrm{ml}^{-1}\right)\end{array}$ & $\begin{array}{c}\text { Correla tion } \\
\text { Coefficient } \\
\text { (r) }\end{array}$ & $\begin{array}{c}\text { Molar } \\
\text { absorptivity } \\
\left(\mathrm{I} \mathrm{mol}^{-1} \mathrm{~cm}^{-1}\right)\end{array}$ & $\begin{array}{c}\text { LOD } \\
\mu \mathrm{g} \mathrm{mL} \mathrm{mL}^{-1}\end{array}$ & $\begin{array}{c}\text { LOQ } \\
\mu \mathrm{g} \mathrm{mL} \mathrm{m}^{-1}\end{array}$ & Reference \\
\hline F.C & 752 & $25-150$ & 0.9977 & $1.47 \times 10^{3}$ & NA & NA & 12 \\
\hline MBTH/Fe(III) & 665 & $50-300$ & 0.9999 & $.455 \times 10^{3}$ & NA & NA & 12 \\
\hline PDAC & 463 & $25-150$ & 0.9999 & $1.76 \times 10^{3}$ & NA & NA & 12 \\
\hline СTC & 620 & $10-50$ & 0.9999 & $9.58 \times 10^{3}$ & $3.07 \times 10^{-1}$ & $9.3 \times 10^{-1}$ & $\begin{array}{c}\text { Present } \\
\text { paper }\end{array}$ \\
\hline
\end{tabular}

FC: Folin Ciocalteu reagent, MBTH:3-methyl-2-benzothiazolinone hydrazone

PDAC: $p$-Dimethylamino cinnamaldehyde, CTC: Cobalt thiocyanate

per $\mathrm{ICH}$ guidelines ${ }^{18}$ for its linearity, precision, and accuracy, limit of detection and limit of quantification. Regression analysis using the method of least square was made to evaluate the slope (b), intercept (a), and correlation coefficient(R) obtained from different concentrations of drug. The result of slope $\left(1.43 \times 10^{-2}\right)$ and intercept $\left(1.2 \times 10^{-3}\right)$ of drug by the proposed method was given in Table 2 .

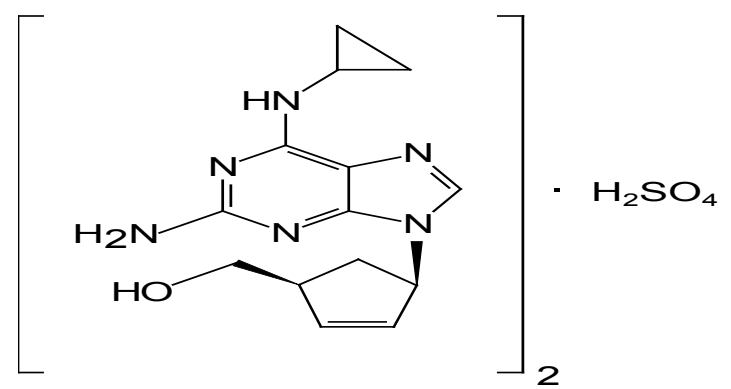

Fig. 1: Structure of Abacavir Sulphate

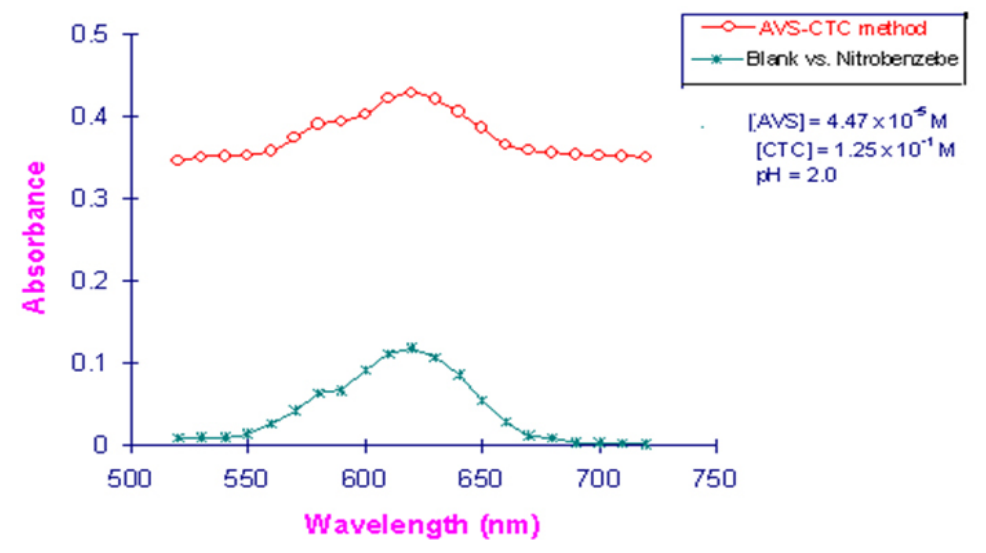

Fig. 2: Absorption spectrum of AVS - CTC method

\section{Linearity}

Linearity was found in the concentration range $10-50 \mu \mathrm{g} \mathrm{mL}^{-1}$. Beer's law plots $(\mathrm{n}=6)$ were linear with a correlation coefficient of 0.9999 (Table 2)

\section{Limit of detection (LOD) and limit of quantification (LOQ) \\ Limit of detection (LOD) and limit of} quantification (LOQ) were established according to $\mathrm{ICH}$ guidelines and determined by using the formula $\mathrm{LOD}=\mathrm{K} . \mathrm{SDa} / \mathrm{b}$ where $\mathrm{K}=3.3$ for LOD and and 
10 for LOQ. SDa is the standard deviation of the intercept and $b$ is the slope of the calibration line. LOD and LOQ were found to be as low as $3.07 \mathrm{x}$ $10^{-1} \mu \mathrm{g} \mathrm{mL}^{-1}$ and $9.3 \times 10^{-1} \mathrm{mg} \mathrm{mL}^{-1}$ respectively. The results are presented in Table I.

\section{Precision}

The repeatability of the proposed method was studied by repeating the method six times ( $n$ $=6$ ). To study intra-day precision, the method was repeated six times a day. Similarly, the method was repeated on six consecutive days to determine interday precision. The results are summarized in Table 3.

\section{Accuracy}

The accuracy of the method was determined in terms of \% recovery of AVS standard. Recovery studies were carried out by addition of standard drug solution at three different levels $\left(8,10,12 \mu \mathrm{gL}^{-1}\right)$ to previously analyzed sample (tablet) solution. Values of recovery \pm SD were found to be in the range of $99.7 \pm 0.7-100.2 \pm 1.2(n=3)$. The results are given in Table 4.

\section{Selectivity studies}

The extents of interference by various excipients that often accompany pharmaceutical formulations are tabulated in Table-6. To study the interference, $100 \mathrm{mg} \mathrm{mL}^{-1}$ of AVS was taken and a known amount of the interfering substance was added and the reaction was carried out as described under general procedure. The interference studies were carried out by repeating the method five times. The results showed the same absorbance as that of pure AVS. The high percentage of recovery showed that excipients did not interfere with the proposed method and the results are presented in Table 5.

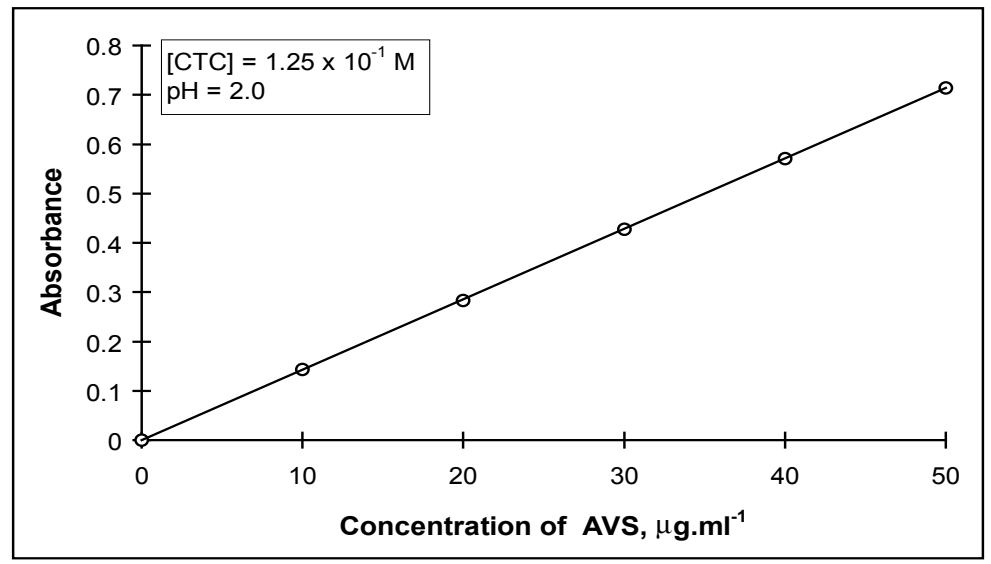

Fig. 3: Beer's law plot of AVS-CTC method<smiles>C[C@H]1CC1Nc1nc(N)nc2c1ncn2[C@H]1CC[C@H](CO)C1</smiles>

(Secondary Amine)

Scheme 1: Extraction of co-ordination complex in nitrobenzene for abacavir sulphate 


\section{Application of the proposed method}

The application of the proposed method for the assay of pharmaceutical formulations was examined for tablets and the results were statistically compared with those obtained by UV reference method. The results obtained by the proposed and UV reference method for the formulations were compared by means of Student's $t$-test and $F$ - test and it was found that the proposed method do not to differ significantly in precision and accuracy. The results are summarized in Table 6.

The results obtained by the proposed method are compared with reported methods ${ }^{12}$ and found to be more sensitive in the range of 10$50 \mu \mathrm{g} \mathrm{mL}{ }^{-1}$ with $\mu_{\max }$ value $9.58 \times 10^{3} \mathrm{~L} \mathrm{~mol}^{-1} \mathrm{~cm}^{-1}$. Other analytical parameters like limit of detection (LOD) and limit of quantification (LOQ) were also be evaluated for proposed method but not available in reported methods. The advantage of proposed method is that it requires less expensive equipment, low cost reagents and also free from stringent conditional procedures. The results are given in Table 7.

\section{CONCLUSIONS}

In the present study abacavir sulphate was determined successfully as pure compound as well as in formulations by exploiting specific functional group present. The proposed method is sensitive, accurate and precise enough to be successfully adopted as an alternative method of GLC or HPLC technique for routine analysis and also in quality control laboratories for quantitative determination of drugs both in bulk material and dosage forms without interference from excipients and additives.

\section{ACKNOWLEDGEMENTS}

One of the authors (TMS) is thankful to the Management of Gayatri Vidya Parishad College of Engineering (Autonomous), Visakhapatnam for providing facilities

\section{REFERENCES}

1. Dogan B, Uslu B, Ozkan SA \& Zuman P, Anal Chem, 80: 209 (2008).

2. Shanta Kumari A, Prakash K, Nagoji KEV \& Rao MEB , Asian J Chem, 19: 3412 (2007)

3. Sudha T, Ravikumar VR \& Hemalatha PV, Int. $J$ of Pharm \& Biomed Res., 1(4): 108 (2010).

4. Seshachalam U, Haribabu B and Chandrasekhar KB, J of Separation Sci, 30(1): 28 (2007).

5. Raviolo MA, Breva IC \& Esteve-Romero J, J of Chromatography A, 1216(16): 3546 (2009).

6. Mistri HN, Shrivastav P, Jangid AG \& Sanyal M, Anal. Lett, 40(6): 1147 (2007)

7. Rao RN, Vali RM, Ramachandra B \& Raju SS, J of Pharm and Biomed Anal, 54(2): 279 (2011)

8. Surya Rao S, Imran K, Srujana Divya G, Manikantha Kumar J, Thejonadh K \& Kishore G, Archives of Applied Sci. Res, 2(3): 23 (2010) .

9. B.K. Rai and P. Anand, Orient J. Chem., 28(2): 525-529 (2012).

10. Sudha T, Saminathan J, Anusha K, Keerthi M, Bhargavi Y\& Ganesan V, J Chem Pharm
Res, 2(5): 45 (2010)

11. Appala Raju N, Venkateswara Rao J, Vanitha Prakash K \& Mukkanti K, E-J of Chemistry, 5(3): 511 (2008).

12. Amit Kumar, M.K. Jha and A.K. Jha, Orient J. Chem., 28(2): 895-900 (2012).

13. Venkatamahesh $\mathrm{R} \&$ Dhachinamoorthi $\mathrm{D}$, Int J of Pharm Tech Res, 3(1): 356 (2011).

14. Manikya Sastry $\mathrm{T}$ and Rambabu Int. $\mathrm{J}$ of Chem. and Anal. Sci., 3(8): 1533 (2012)

15. Manikya Sastry T, Trilochan padhi, and K.Ramakrishna, Int. J. Chem. Sci., 7(2): 1045 (2009)

16. Manikya Sastry T, Muralimohan Rao S V, and K.Ramakrishna, Int. J. Chem. Sci., 7(2): 1218 (2009)

17. Sastry C S P, Lingeswara Rao J S V M \& Rama Rao K, Talanta, 42: 199 (1979) .

18. Adelusi S A \& Oneyekweli A O, Pak. J. Sci. Ind. Res., 39: 22 (1996).

19. International Conference on Harmonization of Technical Requirements for Registration of Pharmaceuticals for Human Use, ICH Harmonized Tripartite Guideline, Text and Methodology on Validation of Analytical Procedures, Q2 ,R1 (2005). 